The Poetry Garden: Ecoliteracy in an Urban School

by

VERONICA GAYLIE

University of British Columbia, Okanagan

Biography

Veronica Gaylie is assistant professor of Education at the University of British Columbia, Okanagan. She directs eco-centred middle school teacher education, founded a campus "Learning Garden" and teaches Environmental Educations in the faculty's graduate program. Also a poet, Veronica's work has appeared in numerous national and international journals

\begin{abstract}
What is the role of poetry in developing ecoliteracy in urban schooling? While current educational and political discourse calls for 'sustainable' management of the earth's resources, leading environmentalist educators state that a shift in practice must be preceded by a shift in perspective that includes first-hand awareness of local environments. This interdisciplinary, narrative inquiry took place over a two year period to examine how students at a low ranked, inner city elementary school write poetry about their environment as a form of ecoliterate knowledge.
\end{abstract}

\title{
The Poetry Garden: Ecoliteracy in an Urban School
}

And you dare not tell the others

her song rises in you

yet it rises and you sin

secretly to the land

to the land

And then she knows sister/brother, that you belong here too.

- Beth Cuthband, From "For All the Settlers Who Secretly Sing"

(Native Poetry in Canada: A Contemporary Anthology)

\section{Preface}

In elementary school, when the teacher's back was turned, I made lists of things I saw on the way to school:

a red bench 
a blue swing

a green fence

I found little going on inside the classroom that had to do with what went on outside; we faced the blackboard, set apart from one another, seated in rows. Classroom language was abstract, the language of discipline, testing, order and rules. In our "Earth" unit, taught for one week in Social Studies 6, we memorized the lexicon of weather (thermometer, barometer, precipitation). We learned the words, and still, we were not allowed to go outside. In school, "Earth" was just a word. Meanwhile, in our urban Canadian rain forest, it poured.

One day, in Grade Five, I sat in school looking at a black and white photograph of a rainswept field with the caption: "Precipitation." I wondered: Where $i$ s this? I asked the teacher, she didn't know. She said the place was not important, that only the word would be on the test. It was not until a Grade Eleven camping trip, where my friends and I accidentally pitched our tent in a riverbed, that I learned that the whole time we were learning the term "Rain Forest" we were actually living in one, albeit an urban version.

That picture could have been right outside our window.

\section{Introduction}

What is the role of creative language as it relates to urban students' contextual awareness of the natural environment? What is the role of poetry in developing ecoliteracy ${ }^{1}$ in urban schooling? While current educational and political discourse calls for 'sustainable' management of the earth's resources, leading environmentalist educators (Bowers 2006, Orr 2004, Shiva 2005, Plumwood 2002, Armstrong 2000) have stated that a shift in practice must be preceded by a shift in perspective that includes tangible, first-hand awareness of local environments. Meanwhile, studies in urban schools examine the role of 'alternative literacies' that exist on the periphery of mainstream classroom language, where students are encouraged to write about the experiences of their local neighbourhoods (Morrell 2002, Keiser 2000). Given the emphasis on localized experience amongst both environmental educators and urban literacy theorists, how might language educators encourage interdisciplinary, ecoliterate, first-hand awareness of students' local environments?

Environmentalist David Orr (2004) states that the current ecological crisis rests on a 'prior disorder of thought' and that instead of rushing to seek the cure for the crisis, society must retrain its thinking away from the relentless race for knowledge that has

${ }^{11}$ Ecoliteracy, a term first introduced by David Orr, is explained by Fritjof Capra as "our ability to understand the basic principles of ecology and live accordingly." From his essay: Mending the Web of Life: Humanity's survival will depend upon our ecological literacy. 
long ignored ecological consequence. Orr criticizes historically abstract systems of academic learning which severed the human need to interact with environment. $\mathrm{He}$ promotes 'ecological intelligence,' and 'the value of being involved in a context/environment you choose not to exploit.' (p.44) Much of Orr's work focuses on the need to develop in young people a genuine appreciation, even love, for the natural world. He questions the study of 'Science without love' and asks: "Why is it so hard to talk about love, the most powerful of human emotions, in relation to science, the most powerful and far reaching of human activities?" (ibid.)

Val Plumwood (2002) suggests that in order to stimulate ecological awareness, the language of learning itself must change: "For the narrative itself...is a key part of the problem, leading us to reproduce continuously the same elements of failure...while we seek desperately for solutions within it." (p.6) As for the term sustainability, she notes: "The often invoked term 'sustainability' tends to obscure the seriousness of the situation..." (p.1)

As environmentalists call for eco-centred, first-hand experiences of nature that include a sense of "love, awe, mystery...[and] caution" (Orr, p.45) for the natural world, there is also a need for discourse that will permit and inspire such awareness. How can educators place learning and language in the context of local, lived experience while ensuring that diverse perspectives, and a variety of local environments, are given voice? How might poetry deepen understandings of the role of language, literacy and urban ecology?

In poetry, 'poetry slam' champion and secondary student April Hale describes her sense of language, ecology and learning from a First Nations' perspective:

\section{Butterfly}

Freedom has many exotic colours

that light up the darkness

and darken the brightness

Colours that change in the sunlight

Colours that change in the moonlight.

\section{Description of the Study}

This interdisciplinary, narrative inquiry examines how inner city elementary students at a low-ranked school write creatively poetry about their environment as a form of ecoliterate knowledge. The poetry included here was written by urban, inner city, Grade 6/7 students in one of the lowest ranked schools in the province of British Columbia. The school is located in Vancouver's downtown eastside, with a high aboriginal population and a high ESL population; the majority of the students in the school live at or below the poverty line. Of the twenty-four students in the class, thirteen have been ministry 'designated' for learning and behavioural challenges. The school is also involved in one of the longest standing school garden projects in the country, where organic produce is cultivated for the school and neighbourhood community. 
This study describes writing poetry in the school garden and in the nearby surroundings, with the students, their classroom teacher, and myself, over a two-year period. Students were invited to write poetry in their local environment through a variety of creative writing activities that included 'free-writing' on ecology-related topics such as 'bioregion,' 'native plants,' and 'endangered species.' The poems included in this piece are intertwined with prose, a narrative technique intended to embody the inclusion of creative expression in the midst of a dialogue focused on 'environment,' an area historically associated with the discipline of Science in formal schooling. ${ }^{2}$

\section{Poems from an Urban School Garden}

Weather is a form of communication. (Kunitz, 2005, p. 62)

The teacher described the transformation of the students as they began to write poetry in the garden as "exceptional, dramatic, life-changing, huge." In a recent interview she told me that the main changes she observed in these students, specifically in the context of this school, were about 'pride' and 'freedom.' She noted that when they began writing poetry, their classroom participation and academic work improved with the rise in selfesteem. The First Nations co-ordinator at the school stated that writing poetry in the garden was a 'safe way of journaling,' a way to speak, and 'hide,' in metaphor and symbol. Over time, natural elements provided symbols for the often hidden socioeconomic burdens carried by many of the students. As the classroom teacher told me: "They have a lot going on in their lives outside of school to process....every day. It has to go somewhere."

The students wrote poems that named small, concrete details in their surroundings, which had previously gone unnoticed. An emerging theme of the student poetry was the constant juxtaposition of positive and negative reactions to nature, which expresses the students' complex, ambiguous feelings toward their world:

\section{The Sky}

I see the sun shine in front of the clouds in the sky.

Sitting out here in the cold, it fees like I am in the North Pole.

This is great.

The sky is gray and as big as ever.

It was cold outside.

I just had the goose bumps three times

that's why I am called "Nature Cold."

- Nature Cold, Grade 6

\footnotetext{
${ }^{2}$ Student names appear as pseudonyms, chosen by the students.
} 
Permission to write openly about their local environment, in all its forms, meant their place, and their awareness of that place, suddenly became relevant forms of academic discourse. Being 'tuned in' to the context of the classroom, the world outside the classroom, and of the 'bio-diversity' found there, offered an important starting point for learners whose environments are typically expressed negatively, or ignored, by local media and school rankings.

\section{A Poem to Rain}

The rain sounds so quiet and has a low humming noise.

I also hear a police siren in the background faintly.

The rain makes trees look like they are dripping.

When the rain hits puddles it looks like it is making bubbles.

- Mr. Chris "A”, Grade 7

Permitting students' local worlds, written in their own language, in classroom learning became a form of academic and ecoliterate awareness that truly expressed "the concrete nature of educative practice." (Freire 1998, 93). In the inner city classroom, students were delighted to hear the words that surrounded them, East side street names like Hastings, Rupert, Cassiar, included in classroom discussion. The familiarity of the words always made the students laugh in recognition, perhaps because they had never heard the names mentioned in the context of the curriculum before.

When the discussion of 'bioregions' lead to a discussion of 'bodies of water,' the students talked about what they knew: Trout Lake, a small lake located in a nearby city park. I then asked the students to write a poem called "The Body of Water I Know." Many of the students focused on an even more familiar body of water: the puddles outside their homes, on their sidewalks, in their street gutters and school puddles. Instead of naming the larger local bodies of water (including the nearby Pacific Ocean and the Fraser River) the students began with puddles, a largely unnoticed 'body of water' right outside their door. They constantly moved from local to universal ecological awareness with a sense of creativity, freedom and agility.

Body of Water

The bodies of water I know are the puddles.

It looks like mini lakes.

It sounds like a rain drop, I step on it.

It smells like mud.

The body of water I know is a puddle that looks like the three great lakes of Ontario.

- Rosetta, Grade 6

Body of Water 
The body of water I know is the Gulf of Mexico.

Looks like a giant bowl of water with a large piece missing.

Sounds like chaos and smells like fish.

The body of water I know is the Gulf of Mexico

and it's smelly, chaotic, and big but it will always be

the Gulf of Mexico.

- Antonio Montana, Grade 6

It was typical for the students to defy expectations, challenge all assignments, in order to make it their own. These students would never try to write a poem 'correctly' to please the teacher, or myself, or anyone else. For example, the day I brought in materials to make crowns, only one made a crown and the rest made...belts, wall hangings, placemats and other items to decorate their homes. The students constantly surprised me with their creative interpretations of activities. I had never, until that day, thought of an urban puddle as a 'body of water,' a concept that is so simple and true it seemed impossible to miss. Inclusion of their own, unique metaphors added to their body of writing on urban ecology which not only reflected their surroundings, but also their struggles.

Rain

Oh rain you are so wet and

gross

When you visit I think I

can't do any thing

outside

I wish you would dry up

and go away.

You sound like....I really don't know.

- AKA Shorty, Grade 7

AKA Shorty's poem, without an easy metaphor for rain, expresses the student's sense of ambiguity. Unconditioned to what 'a poem' looks and sounds like, the student engaged in unsentimental, ecoliterate awareness, that projects an acute, close, honest awareness of her surroundings. The student's words reveal questions. What does rain sound like? Is there a right answer? Such a poem also challenges a teacher's expectation for what poetry should look like and sound like as it relates to a changing natural world. Should rain always sound like 'a drum beat'? A 'crackling fire'? The poem's ambiguity also permits a reconsideration of the culture of language and literacy, and highlights a need 
for learning beyond 'correct definitions' and 'right answers' to a language that offers learners a way to reflect openly on their worlds.

The day the students wrote haikus to each other, they were excited to hear their own names in poems. The descriptions of the garden, the surrounding neighborhood, the bleakness, the brightness, and the plainness of their worlds all carried meaning once they heard it read aloud. In fact, reading through all of the student poems, 'contrast' was a common, ongoing theme:

Ode to Rain

Oh Rain you are so fast as you pat my head and send a cold

echo through my body. When you visit I think of a sad and hollow

day when no one cares. Sometimes I wish you can just stop turning

the sky gray and stealing the sun. When I watch you through my

window I only hear rapid taps and I see no motion but falling rain,

And puddles. you sound like thumps over and over.

- Antonio Montana, Grade 6

Ode to Rain

Oh rain you are so sweet and boring and loud too.

When you visit I think of little rocks hitting a vast drum.

I wish that you keep raining for plants and animals.

When I watch you outside I see little drops of rain and seeing the little circles on the pavement of the effects of rain.

I hear you sound like little rocks hitting a roof while sprinkling down the side

- Mister Roger, Grade 7

This Fine Wednesday March 28

Here we are with a pencil and paper. 
Nice and pretty clouds, and not even loud.

I went outside to see a nice day, of if it just was May.

A nice pretty garden with nice pretty plants. A nice pretty environment, with nice pretty nature.

Some people were sitting down lonely, some people were sitting down happy. It's a sunny day, but a cold day.

- Valentin, Grade 6

The poems' contrasts reflect both a mysterious and a vernacular understanding of the natural world. In Antonio's poem, the colour and sound, the gray and the tapping, add to a mood of claustrophobia and emptiness. Antonio, an immigrant from Mexico, later told me that the best thing he liked about the poetry project was 'noticing the details.' He said it made him feel 'a part of the world.' While Mister Roger's poem describes 'the little circles' and 'the effects of rain', and Valentin's 'beautiful' but 'cold' day reflect both loneliness and happiness, all three poems evoke an ecoliterate awareness, where students describe their understanding of action and ecological consequence in the natural world.

In these poems, students use language as a means of both describing nature, and of identifying with their urban environments. When reading the poems aloud, the students began to hear in their own work, and in the work of others, the connections between the students, the surroundings, and the organic contrasts in both. Closely observing the uncomplicated contrasts in nature made students' aware of the contrasts and changes within themselves. It was rainy one day, sunny the next and both were accepted and acceptable, in nature, and in poetry. Difference, contrast and change, core characteristics of their everyday lives, seemed organic and 'normal' within the natural world.

The students developed a sense of wonder at just being outside, writing. The stance of 'watching and waiting,' while student's quietly examined nature and wrote poetry in the school yard, was not a typical characteristic of the group. Later, the teacher told me that the first time she saw them lined up beside the fence across from the Skytrain, writing, she was in a bit of disbelief, and said to herself: "My God. They're writing poems!"

In Spring they crowded under the massive, pink flowering tree outside the front of the school and studied the tree in quiet wonder.

This Fine Wednesday March 282007

Here we are with a pencil and paper

We went outside to the garden to discover everything in the garden

At first it was calm now its loud

It felt cold but it warmed up 
People were whispering and talking

I saw everything in the garden wondering

who, where, why, when and how it was made I

heard everything and still wonder.

- AKA Shorty, Grade 7

This Fine Day

We went to the garden to discover the beauty of nature,

At first it was quiet then it felt windy

People were quiet and still

I saw birds flying above the sky roaming around

- Bob, Grade 6

AKA Shorty's line, 'I saw everything in the garden wondering,' juxtaposes the student's sense of small and large, local and universal understanding, while again leaving more questions than answers. In Bob's poem, the student starts out on the ground, going to the garden, and within a few lines, the birds are flying above the sky roaming...' The poets describe their self-awareness through the quiet in nature, an attitude they did not often reveal when inside the classroom. In fact, they were often reluctant and shy at showing any kind of subjective, individual, or emotional reactions inside. For example, on my last visit of the year, when, interviewing the students in a group, one said: I hate poetry! Moments later, the same student quietly handed me a card that contained an ode to poetry. The students themselves, like their poems, were constant expressions of contrast.

Rainy Days

This cold rainy day full of cold suffering so cold that no on can say a word...

The long silence hurts me from the inside out.

The everlasting raindrops falling on the unforgiving concrete.

A true way to show our feeling of the cold rainy days.

I see the water hitting trees so beautiful.

It reminds me of a waterfall violently hitting

the big hard undeserving rocks below....

- Richelyn, Grade 7

The poems often describe a sense of resilience in nature; survival is found in the contrasts, and in the awareness, of life and nature constantly in flux. Richelyn's line, "A true way to show our feeling of the cold rainy days," describes how the written word provides a successful entry point for students who have found it difficult to begin. These 
students write about their own world, not the one written for them. The poems are not filled with dense language; they are not written by 'trained' poets. The startling magic of the poems lies in the descriptions themselves, in the evocations of imperfect surroundings that are part of the students' daily, urban ecology. As they name it in their own words, they also re-imagine those ecologies. The poems sparkle because the students find unique words for their own landscapes; poetry is a pathway for expression rooted in their concrete surroundings.

\section{This Fine Day}

On this fine day I see plants most dead but some lively... I see birds travelling and chirping. Also dirt as quiet as my lips are now with a car beeping like a microwave when its done. I see a skytrain almost Quiet as it passes by.

\section{- Jessica Barrot, Grade 6}

As the teacher said, 'these poems are real' and have a purpose in encouraging student pride and freedom. One day I asked the students to describe their classroom as an ecosystem. What makes an eco-system? I asked. What makes a world?

\section{Living Awesome Things}

The parts of our classroom eco-system are the plants and the people that surround us.

The moods of our classroom eco-system are busy and exciting.

I am part of the classroom eco-system

because I help and respect others.

Our classroom is a world within a world

because we listen to each others feelings.

- Ann, Grade 6

It was important to the students to read and hear their own words within the official walls of the classroom. It was as if permission to write about their local worlds also allowed students an awareness of the ambiguity and stark contrasts in both their surroundings and in themselves, all of which could be included. Poetry was the bridge to a literacy that they helped define, in a way that expressed their sense of an ecoliterate urban ecology. Their worlds belonged in the classroom, their words belonged there, and they began to engage in a way where they could belong too, not as guests, but in the way that the natural world of the inner city location reflected their own inner worlds:

Outside this Monday

As cold as an ice cube 
Fresh air

Wind blowing through the air

Damp as water

Leafs with bumps on them

Whistling wind

People talking

Footsteps chirping birds

my thoughts

gray clouds

birds

people

leaves, rain puddles, fresh air, minty, tangy.

- Antonio Montana, Grade 6

Antonio's description of the garden that (yet another) rainy day includes the gentlest metaphor for the interior and exterior world ("my thoughts/gray clouds"), co-existing in close proximity within a larger, diverse eco-scape. As Ted Aoki (1991) suggests: "In our North American tradition, we tend to appropriate tension negatively. We seem to succumb to an urging within us to reduce it or even eliminate it." (p.183) The urge to create tension-free reproductions of literate awareness is also an ideological underpinning that emphasizes student test scores and school rankings, where daily survival is even a struggle. Permitting the student storm of emotion and experience in the classroom in concrete ways, in turn acknowledges the concreteness of that experience, how it is part of nature, and not to be dismissed as an abstraction or a 'test result.'

When I asked the students to write an ode to an animal, any animal, I received twenty

"Wolf" poems.

Ode to Wolf

Oh Wolf

You are so fast

And you're never last

You are so alive

I hope you survive

- Liamnardo Davinchi, Grade 6

Ode to Wolf

Oh wolf you are wise and swift

You are old and great

I hope you don't die out and stay alive

- Mister Roger, Grade 7 
In so many of the poems written by these students, there is a sense of uncertainty and constant tension within their surroundings. They rarely abandon their surroundings for their imagination or became 'one' with nature. The recognition of themselves within nature was also a good starting point for discussions on ecology. Their voices are firm, concrete, their work always raising more questions than answers:

Ode to Animal

Oh thunderbird

You are beautiful as the moon

And you are stronger than steel

And a free spirit.

I hope that you get lots of room

For the young.

\section{- Carnet Grade 6}

The poems describe strong literacies behind the test scores that annually stigmatize their work. Their work lets the world know they are alive, they are a part of nature and the urban landscape. It seems simple. But encouraging poetic awareness of their own surroundings, including the tension-filled evocations of nature, also permits the very life of the student.

In the week's prior to writing poetry with the students in the garden, there was an accident after school where a car lost control, crossed the sidewalk, and drove into the playground. Members of one family from the school were severely injured. The students did not speak about it with me directly, but, the connection to the incident is made, through poetry:

Some flowers are almost dying in the garden close to the playground.

When we came inside it was warm. People were talking and the school was warm and silent.

Only hearing footsteps from the staircase.

- Nature Cold, Grade 6

\section{Student Poetry in Urban Landscapes: What Are the Lessons?}

Do not now seek the answers, which cannot be given you because you would not be able to live them....Live the questions now. Perhaps you will then gradually, without noticing it, live along some distant day into this answer.

(Rilke, 1934, p. 27) 
What is the role of poetry in promoting ecoliterate awareness in urban schools? Working with the students taught me that whether writing about a tree or a puddle, there is always meaning in one's surroundings; there is also meaning in the connection between the poet and their surroundings. Students closely observed their environments and wrote poems that vibrantly evoked that understanding, in often hidden ways. Writing poetically outdoors taught us that language arrives from experience, resides in the world where we reside, and that we also reside in poetry.

Most of the students at the school begin from places of poverty and social rejection, of violence, fear and defeat. However, they must begin. Students in low ranked schools in low income urban neighborhoods require a newly imagined language and literacy, one based on creativity and acceptance that could also benefit all students who need a way to begin. The call from environmental educators for more experiential learning is an opportunity to develop tangible language and literacies that lends themselves to ecological awareness. Whether a student writes about puddles or oceans, sparrows or thunderbirds, a contextualized literacy encourages students to take root in their surroundings. When we permit students to write in their own voices, we begin valuing and nurturing the connections between one another and extend those connections to the earth. Returning indoors, the students' observations began to form the classroom conversation itself. For these students, poetry allowed the ambiguity necessary for selfacceptance so that conversation could begin.

Environmental educators call for eco-centred decision making in economics, energy use, daily life and in education. Such a radical, ideological shift will not occur until there is a predisposition, a way of thinking and feeling about the earth, that will inspire eco-centred decisions in the first place. In order for us to engage in ecoliterate action with our planet we first "... will need a different manner of thinking about forests that acknowledges forthrightly the limits of our knowledge and our inconsistency in using what knowledge we do have." (Orr, 2004, p. 68)

The poetry study shows how nurturing a quiet, alert, poetic awareness toward the earth in our students provides a predisposition that permits ecoliterate knowledge to emerge. Such awareness, expressed and shared through poetry, moves beyond 'green' jargon to the potential for relevant discourse in marginalized, urban ecologies. And, it all begins with their own, simple awareness. David Orr states:

The cultivation of the sense of wonder...takes us to the edge of mystery where language loses its power to describe and where analysis, the taking apart of things, is important before the wholeness of creation, where the only appropriate response is a prayerful silence." (Orr, 2005, p.99)

Will poetry save the planet? Poetry, as always, is an expression of the world. With a planet in ecological crisis, poetry bears witness from all learners. Allowing students 'in on' their world (the garden, the playground, the street) permits authentic expression within the 'official' interpretations of written classroom language. As various institutions 
speak about 'greening' their corporate missions, poetry, as ever, is a call to attentiveness and wakefulness that speaks to the heart.

What is Green?

Green is jello

Green is frogs

Green is moldy logs from green bogs

- Dark Soul, Grade 7

Perhaps the role of poetry in ecology is its very presence, in how a poem witnesses and teaches. Poetry allows room for smaller ecoliterate narratives that witness the world outside the window:

The gravel field as big as my heart and yet I can't find it.

- Jellybean, Grade 7

Poetry lets silence, through nature, speak.

\section{References}

Aoki, T. (1991). "Sonare and Videre: Questioning the Primacy of the Eye in Curriculum Talk." In Reflections From the Heart of Educational Inquiry: Understanding Curriculum and Teaching Through the Arts. George Willis and William H. Schubert (Eds). New York: SUNY

Armstrong, Jeannette, Delphine Derickson, Lee Maracle and Greg Young-Ing. 2000. We Get Our Living Like Milk From the Land. Penticton BC: Theytus Books.

Bowers, Chet. A. 2006. Revitalizing the Commons: Cultural and Educational Sites of Resistance and Affirmation. Lanham, Md.: Lexington Books.

Cuthband, B. (2001). In Jeannette C. Armstrong, Lally Grauer (Eds.) Native Poetry in Canada: A Contemporary Anthology. Peterborough: Broadview Press.

David, Jack. 1979. Introduction. As Elected: Selected Writing. bp. nichol. Toronto: Talonbooks. 9-29.

Dewey, John. 1902 and 1915 [1990]. The School and Society/The Child and the Curriculum. Chicago: University of Chicago Press. 
Freire, P. 1998. Pedagogy of freedom: Ethics, democracy and civic courage. Lanhman: Rowman and Littlefield.

Hale, A. (1998). "Butterfly." In Gatherings Volume IX: The En'owkin Journal of First North American Peoples. Greg Young-Ing (Ed.) Penticton: Theytus Press.

Kunitz, S. 2005. The Wild Braid: A Poet Reflects on a Century in the Garden. New York: Norton

Keiser, D. (2000). Battlin' nihilism at an urban high school. In K.A. McClafferty \& C.A.Torres (Eds.), Challenges of urban education: Sociological perspectives for the next century. Albany: SUNY.

Morrell, E. (2002). Toward a critical pedagogy of popular culture: Literacy development among urban youth. Journal of Adolescent and Adult Literacy. 46 (1):72-77.

Orr, David. 2005. "Place and Pedagogy," in Ecological Literacy, ed Michael K. Stone, Zenobia Barlow and Fritjof Capra, 85-95. San Francisco: Sierra Club Books.

---. 2004. Earth in Mind: On Education, Environment and the Human Prospect. Washington, DC: Island Press.

Plumwood, A. (2002). Environmental Culture: The Ecological Crisis of Reason. New York: Routledge

Rilke, R.M. (1934). Letters to a Young Poet. New York: Norton.

Shiva, Vandana. 2005. Earth Democracy: Justice, Sustainability and Peace. Cambridge: South End Press. 